Article

\title{
Survey on Food Preferences of University Students: from Tradition to New Food Customs?
}

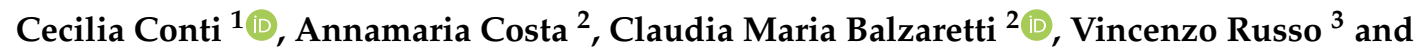 \\ Doriana Eurosia Angela Tedesco 1,*(D) \\ 1 Department of Environmental Science and Policy (ESP), Università degli Studi di Milano, Via Celoria 2, \\ 20133 Milano, Italy; cecilia.conti@unimi.it \\ 2 Department of Health, Animal Science and Food Safety (VESPA), Università degli Studi di Milano, \\ Via Celoria 10, 20133 Milano, Italy; annamaria.costa@unimi.it (A.C.); claudia.balzaretti@unimi.it (C.M.B.) \\ 3 International University of Languages and Media (IULM), Via Carlo Bo, 1, 20143 Milano, Italy; \\ vincenzo.russo@iulm.it \\ * Correspondence: doriana.tedesco@unimi.it; Tel.: +39-02-503-17906
}

Received: 10 September 2018; Accepted: 2 October 2018; Published: 4 October 2018

\begin{abstract}
Humankind currently consumes more resources than our planet is able to generate. In our web survey, we investigated insects and earthworms, as a possible future food source. We targeted the survey to university students, as the possible future consumers and trendsetters of new food. A total of 3556 university students (18-29 years old) completed it. The aims of this study were to evaluate participants' food preferences and their willingness to taste foods containing terrestrial invertebrates. Data were processed using Cronbach's alfa to assess the reliability of each constructs. The food preferences showed pizza-focaccia and pasta at the highest rankings, followed by fruit and vegetables. Males have a higher preference for any kind of animal protein source. Gender influenced food preference and willingness to eat food with insect or earthworm ingredients. The results indicated that students were prone to consider novel food into the Italian diet and to familiarize with them in the future. Insects/earthworms were more accepted in salty snacks. Highlighting the essential amino-acids daily requirements of a snack with earthworm meal did not improve the willingness to taste it. Information and awareness of future global food demand can play a fundamental role in accepting new food.
\end{abstract}

Keywords: university students; food preference; insects; earthworms; gender

\section{Introduction}

Humankind currently consumes more resources than our planet is able to generate. The world population and the global food demand are increasing, particularly the demand for animal protein sources, the most limiting and expensive in terms of resources [1,2]. Since 2003, the Food and Agriculture Organization of the United Nations (FAO) has been examining the food potential of edible insects and the implications for a sustainable way to produce food as an answer to the increased global food demand, particularly focused on animal-based protein sources [3]. Nutritionally, insects contribute greatly to the dietary intake of protein, unsaturated fatty acids and micronutrients such as minerals and vitamins [4]. In addition to insects, other terrestrial invertebrates such as edible earthworms, which are rich in essential amino acids basic of healthy diet, can contribute to food protein production $[5,6]$.

The introduction of new food is likely to be the right approach for sustainable living. Edible invertebrates have a higher feed-conversion efficiency than conventional livestock [7-9]. Moreover, they produce far less greenhouse gases than conventional livestock and have low requirements for 
space and water during the rearing process [3,9]. Thus, eating invertebrates can be considered ethical because it improves food sustainability in terms of minor global warming potential, of land and water use [10-12].

In most European countries, human consumption of insects is considered culturally inappropriate or even taboo, as they are considered disgusting and dirty [13]. Food neophobia is a determining factor towards acceptability of insects [3,14-16]. In European countries, another fundamental reason why insects are underappreciated is their almost total absence in the market, due to laws restrictions [17]. Still, across the European Union (EU), member states adopted different interpretations of the regulation (EC) No 258/97 on novel foods. For example, the United Kingdom considered that whole animals, and therefore whole insects, were outside the scope of the Novel Foods Regulation (EC) No 258/97 [18], which refers to ingredients/parts. Considering other member states, insects as food for humans were sold, traded and consumed in the Netherlands [19] and Belgium [20].

From the 1st January 2018, the placing on the market within the European Union of traditional foods from third countries, i.e., insects, should be facilitated where the history of safe food use in a third country has been demonstrated [21]. Besides the legislative aspects, the emotional acceptance is the main barrier to insects' adoption as food [22]. To pursue this goal, communication plays a crucial role in information dissemination and food habit changes $[16,23,24]$.

Several studies have been conducted in Western countries to evaluate the introduction of these foods into the diet $[15,16,25-27]$. Most of these studies have shown a reluctance to include insects in the diet, which are, however, more easily accepted if processed or as ingredients inside familiar food items $[22,25,28,29]$. Similar results have been obtained for Italian consumers as well $[23,24,30]$.

Although various authors investigated insects acceptability $[15,16,25,26,31]$, earthworms as food are a new subject of study. We also focused on earthworms as food, since the macro research project is about the "bioconversion of fruit and vegetable waste to earthworm meal as novel food source" (see Acknowledgments). Despite their unfamiliarity, earthworms have been used as food [6,32].

The main aim of this study was to evaluate the university students' propensity and willingness towards terrestrial invertebrates (insects and earthworms) as a future food source. These foods were not given to taste since in Italy insects and earthworms are not admitted as food by the law.

An online questionnaire was submitted to university students, because the young generation is considered the most likely early adopters of novel food $[16,25]$ and future food decision makers. To understand the students' food choice in general and their food habits, to begin we investigated their general food preferences. Differences between males and females in terms of food preference were identified.

Food preferences are influenced by both age and gender [33,34]. Tan et al. [22] reported that investigations are necessary to identify which insect-containing products have a higher acceptance. In our online survey, we asked participants their willingness to taste different familiar foods with insects or earthworms among the ingredients. Given that gender strongly influences consumer acceptance towards unfamiliar foods $[16,27]$, we have analyzed the effect of gender on foods with terrestrial invertebrates' ingredients.

Since this study proposed new food as a sustainable way to produce food in terms of minor global warming potential, of land and water use, to evaluate the students' awareness of this topic, questions concerning environmental food sustainability have been asked.

\section{Materials and Methods}

\subsection{Participants}

An online survey was administered to the students of the University of Milan (UNIMI), International University of Languages and Media (IULM) and University of Bari (UNIBA) between May and June 2016. We used a random stratified sample with two strata, North and South Italy. For Northern Italy, we carried out the survey in Milan, the most representative university 
town; for the South, we considered Bari as the greatest academic referring point. This specific target of age-young adults-was chosen because representative of future consumers of terrestrial invertebrate-based products.

A total of 3556 university students (18-29 years old), 69\% females and 31\% males, completed the online survey. Non-Italian students were not considered in order to focus on Italian people. The questionnaire for the evaluation of participants' food preferences and their willingness to taste foods containing terrestrial invertebrates was administered via institutional mail addresses, sending a short explanation about the topic of the study and a web link for the survey completion. We wanted to evaluate their awareness about environmental sustainability of food, which is a topic frequently discussed in the media and also included in some university courses. The survey was directed to participants living in Italy, a country with an ancient tradition in food. The invitation to participate in the survey was forwarded by sending an e-mail to students. The e-mail and the introduction to the online questionnaire explained the aim of the study, provided the guarantees of anonymity of the investigation. Participants anonymously completed the survey using their own electronic devices with no financial incentive for completing it. The questionnaire was written in Italian. Before the online submission, the questionnaire was proposed and discussed in one university course as a pilot study to verify whether the items could be clearly understood by the participants. Subsequent to this phase, the final questionnaire version was developed and was distributed using SurveyMonkey (SurveyMonkey Inc., Palo Alto, CA, USA).

\subsection{The Survey}

The questionnaire, which consisted of 44 questions, was divided into five question sections: (1) sociodemographic information; (2) food preference; (3) future of terrestrial invertebrates' introduction in the Italian food scenario; (4) future of invertebrates' integration into the Italian diet; and (5) food and environmental sustainability.

In Section 1, participants could read about the topic of the survey: "Nutrition plays a leading role in our daily lives. Nutrition has many implications, from human to environmental health without neglecting the animal one. Italian universities are involved in this research to evaluate new forms and types of food of the future culinary landscape". Then, an estimation of the time necessary to complete the survey was given (10 min).

In this part, the participants were asked to answer multiple-choice questions regarding age, gender and other sociodemographic information (e.g., citizenship, marital status, etc.).

\subsubsection{Food Preference}

In Section 2, respondents were tested at individual food preferences with a list of different type of foods, from the more traditional food consumed in Italy (pasta, pizza, etc.) to less frequently eaten food (snails, frogs, caviar, etc.). Their food preference was rated on a seven-point Likert scale verbally anchored at the ends with "Do not like at all" $(=1)$ and "Like extremely" (=7).

\subsubsection{Future of Terrestrial Invertebrates' Introduction in the Italian Food Scenario}

The third section consisted of questions related to the propensity towards the introduction of terrestrial invertebrates in the Italian food scenario. Before these questions, few lines to describe this possible future food scenario were given to participants: "The future trend of the culinary landscape seems to propose dishes and recipes with terrestrial invertebrates. Examples are the trendy restaurants in Copenhagen and in London". The questions about willingness to taste terrestrial invertebrates were structured starting from students' expected familiarization with terrestrial invertebrates: "Do you believe that Italians could become familiar with novel food, as it happened for sushi (raw fish), absolutely unfamiliar years ago?", "Could terrestrial invertebrates, insects and earthworms that are eaten in other countries be part of Italian diet in the future?". For each question, each participant was asked to respond with the following options: yes, I don't know, no. 


\subsubsection{Future of Invertebrates' Integration into the Italian Diet}

In part 4, participants answered questions concerning their willingness to taste different food preparations containing insect or earthworm ingredients. Five food preparations containing terrestrial invertebrate ingredients were evaluated with acceptability measure: willingness to try [22]. "How much would do you like to taste a food preparations containing insects or earthworms ingredients?" The foods proposed were: salty snacks, sweet snacks, hamburger or meatballs, traditional dishes and vegan/vegetarian dishes. Participants were asked to respond on a seven-point scale from "Do not like at all" (=1) to "Like extremely" (=7). To further test students' willingness to try, the following question was asked: "How much would do you like to eat a snack or a food supplement with earthworm meal that substantially contributes to the nutritional requirements of essential amino acids?" Below this question, participants were presented with a picture of the nutrition information label reporting the essential amino acids supply referred to the daily value reference intake (Figure 1). Willingness to try was rated on a seven-point Likert scale, verbally anchored from at the ends with "Do not like at all" and "Like extremely".

\begin{tabular}{|c|c|}
\hline Nutrition Information & Per $100 \mathrm{~g}$ \\
\hline AMINO ACIDS & $\mathrm{RI} \%{ }^{*}$ \\
\hline Lysine & $57 \%$ \\
\hline Leucine & $37 \%$ \\
\hline Isoleucine & $40 \%$ \\
\hline Valine & $46 \%$ \\
\hline Threonine & $66 \%$ \\
\hline Phenylalanine & $48 \%$ \\
\hline Tyrosine & $37 \%$ \\
\hline Cysteine & $56 \%$ \\
\hline Methionine & $89 \%$ \\
\hline Histidine & $51 \%$ \\
\hline
\end{tabular}

Figure 1. Nutrition information label reporting the essential amino acids supply referred to the daily value reference intake (RI\%) of a snack containing earthworms' meal.

\subsubsection{Food and Environmental Sustainability}

Finally, in Section 5, to evaluate the students' awareness that terrestrial invertebrates could be a sustainable way to produce food in terms of minor global warming potential, of land and water use, the following questions on environmental food sustainability have been asked: "Do you know that the breeding of invertebrates (insects and earthworms) is characterized by low greenhouse gas emissions?" "Do you think it would be possible to breed earthworm as a new human food source by using fruit and vegetable waste, thus helping to reduce the disposal problem?" "Do you think that an innovation in food sources would become necessary considering the scarcity of food resources?" Subjects had to answer the question by choosing one of the following options: yes, I don't know, no.

\subsection{Statistical Analyses}

Statistical analyses were conducted using SAS version 9.2 (SAS Institute, Cary, NC, USA) statistics software. Cronbach's alpha was used to assess the reliability, or internal consistency, of each constructs. Single item standardized factor loadings were all highly significant with values ranging from 0.79 to 0.82 indicating good reliability. The reliability of the willingness to taste a snack or other food 
preparations with terrestrial invertebrates' ingredients was good (0.82). Descriptive statistics were generated using a frequency procedure (Proc FREQ) in SAS. A general linear model (Proc GLM, SAS) was used to test the effect of gender, and its interactions on the proposed food and the willingness to taste it. Results with $p<0.05$ were considered statistically significant.

\section{Results}

\subsection{Food Preference}

The first question was related to the participants' general food-based preference. The preference scores on the proposed food (Table 1) showed that pizza-focaccia and pasta were the favorite ones, with the highest-ranking (6.24 and 6.06 respectively). Fruits (5.97) and vegetables (5.74) followed those traditional Italian dishes. Among the meat foods, fish was more highly rated (5.24) than white meat (5.07) and red meat (4.85). Furthermore, raw fish and sushi, a non-traditional Italian dish, with a mean score of 4.40, showed a high "Like extremely" preference (34.4\%). The less appreciated foods were those not commonly eaten or only locally eaten such as sea urchins (3.06), frogs (2.24) and snails (2.19).

Table 1. Ranking for different food preferences in accordance with mean values, from the higher to the lower food preference $(n=3556)$. Ratings were evaluated on a seven-point response scale ( $1=$ "Do not like at all", 7 = "Like extremely").

\begin{tabular}{|c|c|c|c|c|c|c|c|c|c|}
\hline \multirow{3}{*}{ Proposed Food } & \multicolumn{2}{|c|}{ Food Preferences } & \multicolumn{7}{|c|}{ Food Preferences Frequency $\%$} \\
\hline & & & $\begin{array}{c}\text { Do Not } \\
\text { Like at All }\end{array}$ & & & & & & $\begin{array}{c}\text { Like } \\
\text { Extremely }\end{array}$ \\
\hline & Mean & SD & 1 & 2 & 3 & 4 & 5 & 6 & 7 \\
\hline Pizza-Focaccia & 6.24 & 1.12 & 0 & 1 & 2 & 5 & 11 & 23 & 58 \\
\hline Pasta & 6.06 & 1.30 & 1 & 1 & 3 & 6 & 13 & 23 & 53 \\
\hline Fruit & 5.97 & 1.33 & 1 & 2 & 3 & 8 & 15 & 24 & 47 \\
\hline Vegetables & 5.74 & 1.47 & 2 & 3 & 5 & 8 & 18 & 24 & 41 \\
\hline Rice & 5.72 & 1.29 & 1 & 1 & 4 & 10 & 22 & 28 & 34 \\
\hline Legumes & 5.34 & 1.62 & 4 & 4 & 6 & 12 & 20 & 24 & 29 \\
\hline Bread-Cracker-Breadsticks & 5.29 & 1.44 & 1 & 4 & 7 & 15 & 23 & 25 & 24 \\
\hline Fish & 5.24 & 1.92 & 8 & 4 & 5 & 9 & 16 & 22 & 35 \\
\hline Cheese & 5.23 & 1.95 & 9 & 5 & 5 & 9 & 14 & 21 & 37 \\
\hline Whole foods & 5.10 & 1.65 & 4 & 5 & 9 & 16 & 20 & 22 & 24 \\
\hline White meat & 5.07 & 1.80 & 8 & 3 & 5 & 11 & 21 & 27 & 24 \\
\hline Yogurt & 5.02 & 1.76 & 6 & 5 & 7 & 14 & 22 & 22 & 24 \\
\hline Cured meats & 4.93 & 1.93 & 9 & 5 & 7 & 12 & 18 & 22 & 28 \\
\hline Eggs & 4.92 & 1.67 & 5 & 5 & 8 & 16 & 25 & 22 & 20 \\
\hline Red meat & 4.85 & 2.04 & 11 & 6 & 8 & 11 & 15 & 21 & 29 \\
\hline Sweets and snacks & 4.71 & 1.82 & 4 & 9 & 11 & 17 & 18 & 18 & 23 \\
\hline Milk & 4.56 & 2.03 & 12 & 8 & 9 & 13 & 17 & 17 & 23 \\
\hline Mussels & 4.51 & 2.28 & 20 & 6 & 6 & 9 & 13 & 17 & 28 \\
\hline Raw fish and sushi & 4.40 & 2.49 & 25 & 7 & 5 & 6 & 10 & 13 & 34 \\
\hline Sea urchins & 3.05 & 2.22 & 43 & 9 & 8 & 14 & 7 & 6 & 13 \\
\hline Oysters & 2.84 & 2.19 & 48 & 10 & 7 & 10 & 8 & 6 & 11 \\
\hline Caviar & 2.67 & 2.01 & 48 & 12 & 9 & 12 & 7 & 5 & 7 \\
\hline Frogs & 2.24 & 1.77 & 58 & 10 & 7 & 12 & 6 & 4 & 4 \\
\hline
\end{tabular}

The food preferences were analyzed according to gender for the significant interaction observed $(p<0.001)$. Concerning the gender effect on hedonic food preferences (Figure 2), males liked significantly more than females the food of animal origins, even when it is untraditional food. 


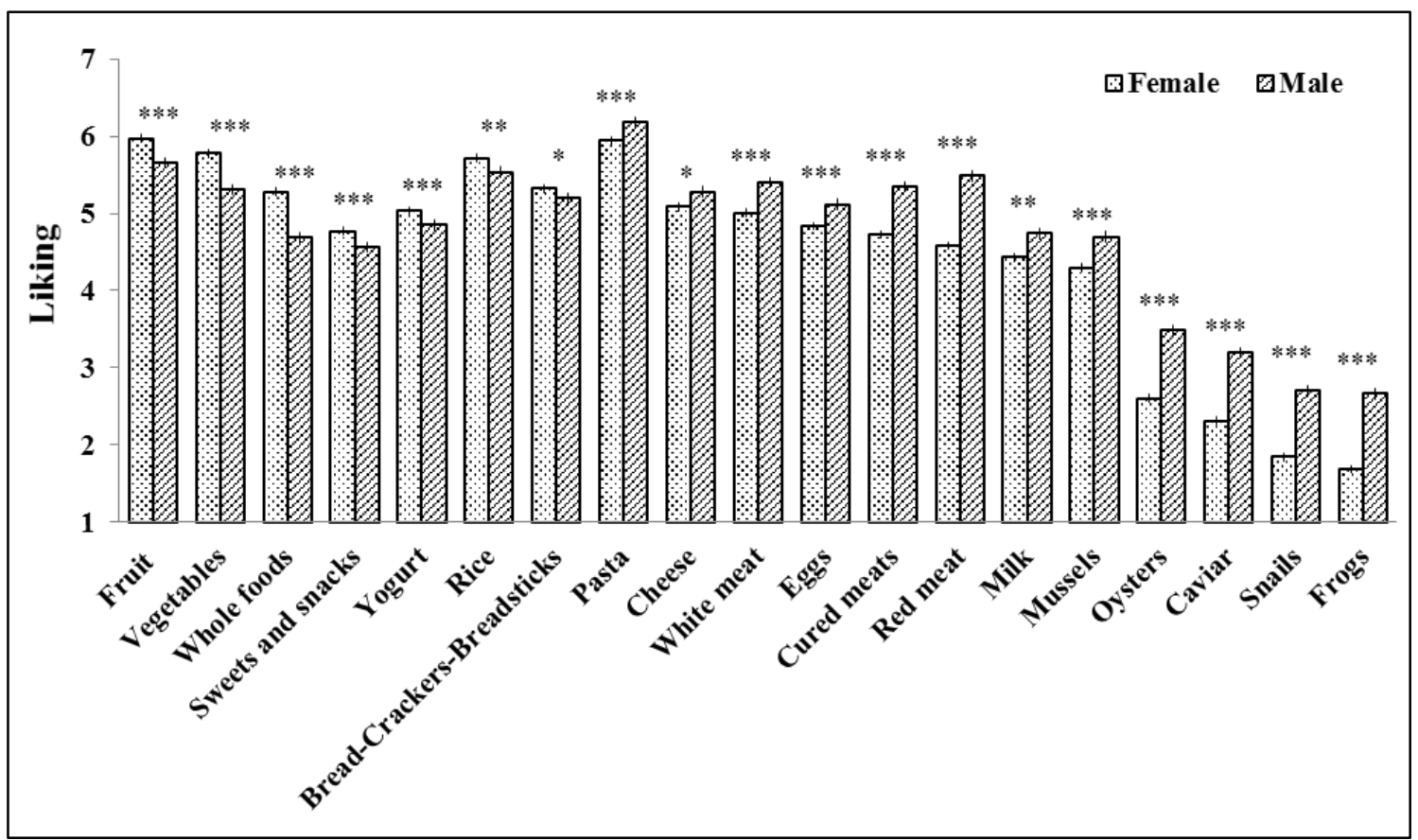

Figure 2. Gender food preference \pm standard error evaluated on a seven-point scale $(1=$ "Do not like at all", $7=$ "Like extremely"). $(n=3556)$. "**" denotes a significant difference at $p<0.05$, “**" at $p<0.01$ and "***" at $p<0.001$.

\subsection{Future of Terrestrial Invertebrates' Introduction in the Italian Food Scenario}

In Table 2 are reported the percentage scores of expected familiarization with terrestrial invertebrates as novel food, and of the expectation of it becoming part of the Italian diet. $50 \%$ of the participants indicated the possibility to familiarize with this kind of food (as it happened for sushi), and $38 \%$ of the respondents were prone to consider that this food could be part of Italian diet. Conversely, the rejected hypothesis were $23 \%$ and $32 \%$ respectively. Twenty-seven percent of the participants said they don't know if it could be possible to familiarize with these foods, whereas $30 \%$ answered that they don't know if it could be part of the Italian diet.

Table 2. Percentage scores on expected familiarization with terrestrial invertebrates as novel food and of the expectation of it becoming part of the Italian diet $(n=3556)$.

\begin{tabular}{|c|c|c|c|}
\hline \multirow{2}{*}{ Questions } & \multicolumn{3}{|c|}{ Participants Responses\% } \\
\hline & Yes & I Don't Know & No \\
\hline $\begin{array}{l}\text { Do you believe that Italians could become familiar with novel food, } \\
\text { as it happened for sushi (raw fish), absolutely unfamiliar years ago? }\end{array}$ & 50 & 27 & 23 \\
\hline $\begin{array}{l}\text { Could terrestrial invertebrates, insects and earthworms that are } \\
\text { eaten in other countries be part of Italian diet in the future? }\end{array}$ & 38 & 30 & 32 \\
\hline
\end{tabular}

\subsection{Future of Invertebrates' Integration into the Italian Diet}

In the present study, the participants were asked to express their willingness to taste different food preparations, from snacks to traditional dishes, containing terrestrial invertebrates, insects or earthworms, as ingredients. The elaboration of results for this section of the survey only considered the answers of those participants that in the previous sections appeared to accept that this novel food could be part of the Italian diet $(n=1351)$. This specific target was chosen to get strategic insights into food preparations with novel food ingredients. As reported in Table 3, the results showed that insects or earthworms were more accepted in salty snacks (4.56) followed by sweet snacks (4.13). As expected, 
terrestrial invertebrates obtained a low degree of willingness in traditional dishes (mean 3.28). Some of the participants considered terrestrial invertebrates as possible ingredients in vegan/vegetarian dishes.

Table 3. Ranking for willingness to taste different food preparations containing insects or earthworms ingredients $(n=1351)$. Ratings were evaluated on a seven-point scale ( $1=$ "Do not like at all”, 7 = "Like extremely").

\begin{tabular}{|c|c|c|c|c|c|c|c|c|c|}
\hline \multirow{3}{*}{$\begin{array}{c}\text { Food Preparations } \\
\text { Proposed }\end{array}$} & \multicolumn{2}{|c|}{ Willingness } & \multicolumn{7}{|c|}{ Degree of Willingness \% } \\
\hline & & & $\begin{array}{c}\text { Do Not } \\
\text { Like at All }\end{array}$ & & & & & & $\begin{array}{c}\text { Like } \\
\text { Extremely }\end{array}$ \\
\hline & Mean & SD & 1 & 2 & 3 & 4 & 5 & 6 & 7 \\
\hline Salty snacks & 4.56 & 1.92 & 13 & 5 & 7 & 14 & 22 & 23 & 16 \\
\hline Sweet snacks & 4.13 & 1.97 & 16 & 9 & 9 & 16 & 21 & 16 & 13 \\
\hline Hamburger/meatballs & 3.98 & 2.11 & 22 & 8 & 10 & 13 & 17 & 15 & 15 \\
\hline Traditional dishes & 3.28 & 2.1 & 31 & 15 & 9 & 13 & 13 & 10 & 10 \\
\hline $\begin{array}{c}\text { Vegan/vegetarian } \\
\text { dishes }\end{array}$ & 3.25 & 2.16 & 37 & 8 & 8 & 15 & 11 & 10 & 10 \\
\hline
\end{tabular}

Then, we analyzed these results by gender as a significant interaction was found $(p<0.001)$. Males showed to be more open to the inclusion of terrestrial invertebrates in all food preparations proposed (Figure 3).

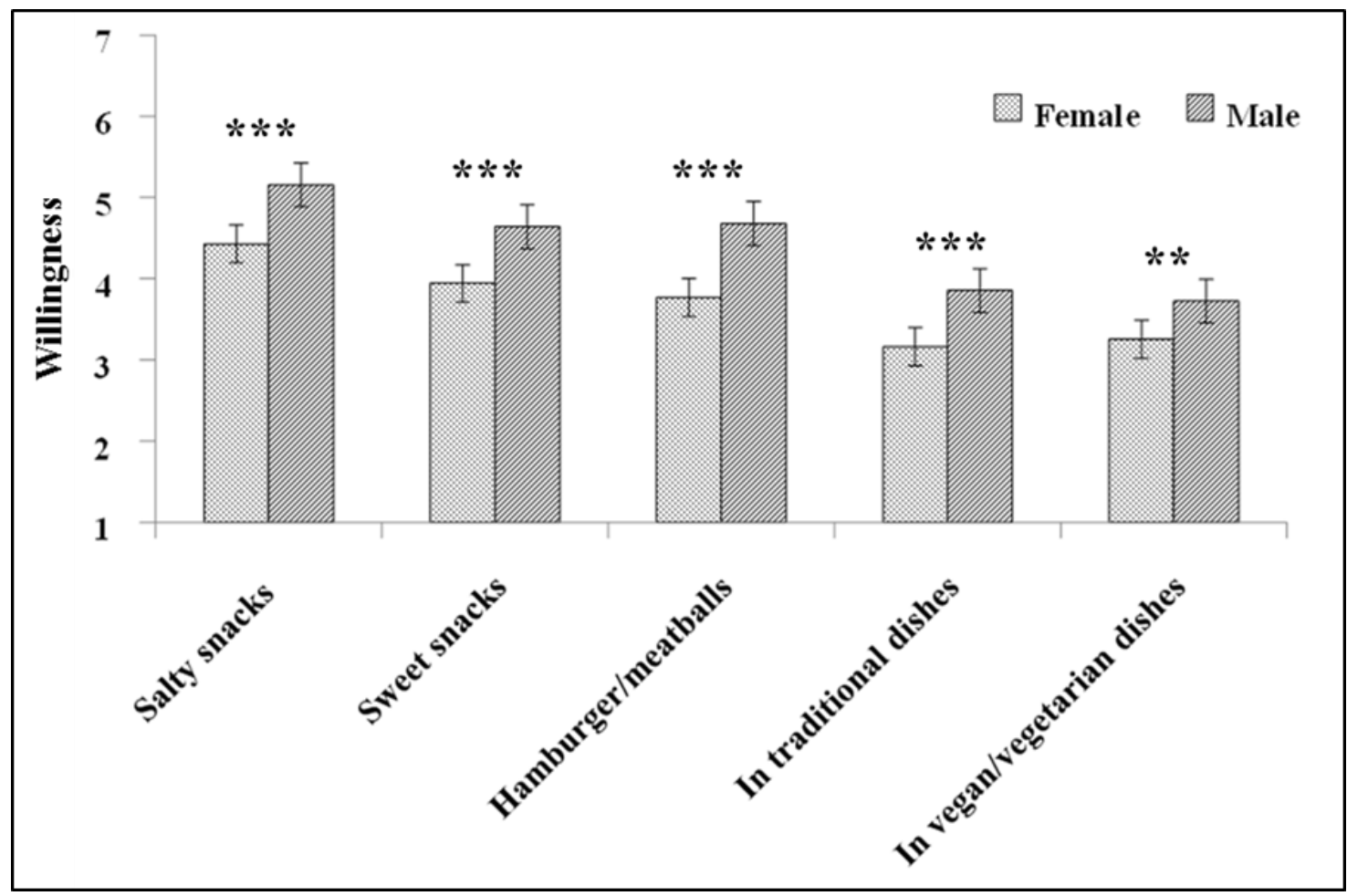

Figure 3. Gender effect on willingness to taste different food preparations containing insect or earthworm ingredients evaluated on a seven-point scale ( $1=$ "Do not like at all", 7 = "Like extremely"). ( $n=1351)$. “*** denotes a significant difference at $p<0.01$ and "****" at $p<0.001$.

The next question was proposed to investigate the degree of pleasure in consuming a snack or food supplement containing earthworm meal, which substantially contributes to the nutritional requirements of all essential amino acids.

In our study highlighting the contribution to the essential amino acids daily requirements of a snack or a food supplement with earthworm meal did not improve the willingness to taste it (Table 4). 
The analysis was done on the same subsamples used for the previous questions. For snacks/food supplement the result was 4.6 with nutritional information and 4.56 without.

Table 4. Willingness to eat a snack containing earthworm meal highlighting the contribution to the essential amino acids daily requirements (Figure 2$)(n=1351)$. Ratings were evaluated on a seven-point scale ( 1 = "Do not like at all", 7 = "Like extremely").

\begin{tabular}{|c|c|c|c|c|c|c|c|c|c|}
\hline \multirow{3}{*}{ Question } & \multicolumn{2}{|c|}{ Willingness } & \multicolumn{7}{|c|}{ Degree of Willingness \% } \\
\hline & & & $\begin{array}{c}\text { Do Not } \\
\text { Like at All }\end{array}$ & & & & & & $\begin{array}{c}\text { Like } \\
\text { Extremely }\end{array}$ \\
\hline & Mean & SD & 1 & 2 & 3 & 4 & 5 & 6 & 7 \\
\hline $\begin{array}{l}\text { How much would you like to eat a } \\
\text { snack or a food supplement with } \\
\text { earthworm meal that substantially } \\
\text { contributes to the nutritional } \\
\text { requirements of essential amino acids? }\end{array}$ & 4.6 & 1.7 & 8 & 7 & 7 & 18 & 26 & 22 & 12 \\
\hline
\end{tabular}

\subsection{Food and Environmental Sustainability}

The participants showed to be well aware of food resource constraints, of high demographic growth and the consequent increasing demand for animal proteins. However, as showed in Table 5, only $38 \%$ of the participants knew that terrestrial invertebrate breeding could further contribute to environmental sustainability thanks to the lower greenhouse gas emissions compared with that of traditional livestock. Most of the participants, $62 \%$ including the "I don't know" and the "No" answers, were not aware of it. One of the submitted questions concerned the use of vegetable food waste as a substrate for the growth of earthworms, the advantage being the bioconversion of this food waste into new food sources. $70 \%$ of the students showed to be sensitive to these issues and that this bioconversion could be a possible solution to the waste disposal problem. Against the scarcity of food resources, $69 \%$ of the participants considered essential to find innovative food sources, in order to cope with the food shortage due to the increasing world population (Table 5).

Table 5. Percentage scores of questions concerning environmental food sustainability $(n=3556)$.

\begin{tabular}{|c|c|c|c|}
\hline \multirow{2}{*}{ Questions } & \multicolumn{3}{|c|}{ Participants Responses \% } \\
\hline & Yes & I Don't Know & No \\
\hline $\begin{array}{l}\text { Do you know that the breeding of invertebrates (insects and } \\
\text { earthworms) is characterized by low greenhouse gas emissions? }\end{array}$ & 38 & 46 & 16 \\
\hline $\begin{array}{l}\text { Do you think it would be possible to breed earthworm as a new } \\
\text { human food source by using fruit and vegetable waste, thus } \\
\text { helping to reduce the disposal problem? }\end{array}$ & 70 & 29 & 1 \\
\hline $\begin{array}{l}\text { Do you think that an innovation in food sources would become } \\
\text { necessary considering the scarcity of food resources? }\end{array}$ & 69 & 26 & 5 \\
\hline
\end{tabular}

\section{Discussion}

\subsection{Food Preference}

In order to consider the nutritional habits and preferences and to characterize the sample, the first question proposed was related to food preferences.

The outcomes regarding food preferences showed that pizza-focaccia and pasta were the favorite food. This finding was expected, since these foods are traditional Italian dishes, confirming the cultural influence in the sample.

In addition, the high ranking of vegetables and fish, before meat products, evidenced an adequate healthy food habit of the participants [35].

Our questionnaire was filled out only by one category of age. Consumers' food preferences are influenced by both age and gender [33,34]. Confirming previous works $[33,34,36-38]$ young females 
evidenced a greater preference for healthy food such as fruit, vegetable and whole foods than males $(p<0.001)$, and also for sweets $(p<0.01)$. Males are more likely to prefer certain food groups, especially meat $[39,40]$ and evidenced a higher preference for products of animal origin, such as eggs, milk, red meat or even oysters and caviar.

If only "Like extremely" preference is considered, among meat products, the first preference was fish, followed by raw fish and sushi, regardless of gender. The fact that sushi, a non-traditional Italian dish, received a high preference did not sound strange. Sushi has now become an accepted food, showing that food preferences are not permanent and may change over time.

In general the participants $(n=3556)$ showed a cultural influence, as Italians, and to prefer healthy and more sustainable food to red meat among other.

\subsection{Future of Terrestrial Invertebrates' Introduction in the Italian Food Scenario}

The results of the present study indicated that the students interviewed claim to be ready to become familiar with terrestrial invertebrates in the future, as has occurred in the recent past with the Japanese sushi. Our findings are consistent with those of previous works where the younger generation was ready to adopt novel food, such as insects [16,25-27], but contrasts with those of Vanhonacker et al. [15] who found that participants had negative attitudes towards the consumption of insects.

\subsection{Future of Invertebrates' Integration into the Italian Diet}

To reduce the reluctance to adopt this particular food, a strategy could be to include it as ingredient in food preparations. The findings of Tan et al. [31] suggested that introduce insects as an ingredient in convenience foods could lower barriers to acceptance. Accordingly, the products containing less visible and more processed insect ingredients tended to be more positively evaluated than the products containing whole insects $[25,28]$.

Considering the participants attitude, the suggested strategy is not to include insects or earthworms in traditional dishes, at least in Italy, a country with a very strong food culture. In a recent review on food preference [41], the least important factor in food choice was "familiarity" and, this was particularly true for the data collected in Italy. On the opposite side a study conducted by Hartmann et al. [27], Germans indicated a higher willingness to eat insects in familiar foods and Tan et al. [31] and Tan et al. [42] also indicated that familiar preparations may improve consumers' acceptance.

Young males appeared to be more open to unfamiliar foods [30,31]. In our study, males showed a low level of neophobia, for example towards frogs and snails, and towards food preparations containing insects or earthworm meal. This result confirms that sociodemographic and age characteristics play a relevant role in consumer food acceptance [16].

Studies on novel food acceptance conducted by Tan et al. [31] and Tan et al. [42] revealed that consumer acceptance is also influenced by information provided by the label. Thus, the inclusion of these particular foods in food preparations enhancing nutritional characteristics can reduce the neophobia. Nevertheless, in our study highlighting the contribution to the essential amino acids daily requirements of a snack or a food supplement with earthworm meal did not improve the willingness to taste it (Table 4). Other than the same subsamples used, the low rating could also be explained by the choice of earthworms that were even less familiar as food than insects. The nutritional information did not seem to affect acceptability and it did not influence students' willingness to eat a snack with earthworm meal. Accordingly, Hartmann et al. [27], Laureati et al. [23] and Verbeke [16] found that information on nutritional benefits did not substantially affect the acceptability. Likewise, de Boer et al. [26] found that only $4 \%$ of their sample would choose a snack containing insects, although snacks were presented as made from environmentally friendly proteins. 


\subsection{Food and Environmental Sustainability}

University students showed to be sensitive to the topics of sustainability, growing population, food scarcity, necessity of alternative protein sources and reduction of food waste. Not surprisingly, because these topics are studied, investigated, and discussed in university courses [23,30]. Moreover, these issues have become a much-debated topic by media and international organizations, such as FAO and United Nations [2,3,43]. Also in previous studies, students showed to be more conscious towards these issues and more open to the theme of novel protein food sources than people from outside the university context $[23,30]$.

\section{Conclusions}

Considering the sample specificity, i.e., university students, the obtained results showed that, at least in theory, young people are open to the introduction of new food and sensitive to food and environmental issues. These are signs of readiness to eat novel food and of a possible increase of terrestrial invertebrates in the European food market. Reasonably, this specific food could be offered in a snack as a complementary source of proteins, considering that demand for proteins cannot be totally satisfied by the traditional livestock industry. The results of the study may help to identify a possible strategy for introducing such food in Italy. The best way would be to introduce terrestrial invertebrates into ready-to-eat preparations where they would not be immediately recognizable. Moreover, an increment of the market share in current market scenario should favor their acceptability.

Some limits are to be considered when analyzing the results. First of all, this food was not actually offered since in Italy insects and earthworms are not admitted as food by the law. A further limitation is the specificity of the sample: but university students were chosen because considered trendsetters of the main innovations. To avoid biases, of course, the results should not be generalized to the Italian population. Further studies on different types of consumers, with different sociodemographic and age characteristics, are recommended, including tasting sessions.

Author Contributions: Conceptualization, D.E.A.T., V.R. and C.M.B. Investigation and data curation, D.E.A.T. and V.R. Methodology, A.C. Writing-original draft preparation, C.C. and D.E.A.T. Funding acquisition, D.E.A.T.

Funding: This research was funded by FONDAZIONE CARIPLO Integrated research on industrial biotechnologies 2015 (project n. 2015-0501): "Bioconversion of fruit and vegetable waste to earthworm meal as novel food source".

Acknowledgments: The authors would like to thank Gaetano Vitale Celano for sending the survey to the students of his courses.

Conflicts of Interest: "The authors declare no conflict of interest". "The funders had no role in the design of the study; in the collection, analyses, or interpretation of data; in the writing of the manuscript, or in the decision to publish the results".

\section{References}

1. Alexandratos, N.; Bruinsma, J. World Agriculture towards 2030/2050: The 2012 Revision; ESA Working Paper No. 12-03; FAO: Rome, Italy, 2012.

2. United Nations. The Impact of Population Momentum on Future Population Growth; Population Facts No. 2017/4; United Nations: New York, NY, USA, 2017.

3. Van Huis, A.; Van Itterbeeck, J.; Klunder, H.; Mertens, E.; Halloran, A.; Vantomme, P. Edible insects: Future Prospects for Food and Feed Security; Food Agriculture Organization of the United Nations: Rome, Italy, 2013; Volume 171.

4. Rumpold, B.A.; Schlüter, O.K. Nutritional composition and safety aspects of edible insects. Mol. Nutr. Food Res. 2013, 57, 802-823. [CrossRef] [PubMed]

5. Cayot, N.; Cayot, P.; Bou-Maroun, E.; Laboure, H.; Abad-Romero, B.; Pernin, K.; Seller-Alvarez, N.; Hernandez, A.V.; Marquez, E.; Medina, A.L. Physico-chemical characterisation of a non-conventional food protein source from earthworms and sensory impact in arepas. Int. J. Food Sci. Technol. 2009, 44, 2303-2313. [CrossRef] 
6. Grdiša, M.; Gršić, K.; Grdiša, M.D. Earthworms- role in soil fertility to the use in medicine and as a food. ISJ Invertebr. Surviv. J. 2013, 10, 38-45.

7. Nakagaki, B.J.; Defoliart, G.R. Comparison of diets for mass-rearing Acheta domesticus (Orthoptera: Gryllidae) as a novelty food, and comparison of food conversion efficiency with values reported for livestock. J. Econ. Entomol. 1991, 84, 891-896. [CrossRef]

8. Oonincx, D.G.A.B.; van Itterbeeck, J.; Heetkamp, M.J.; van de Brand, H.; van Loon, J.J.; van Huis, A. An exploration on greenhouse gas and ammonia production by insect species suitable for animal or human consumption. PLoS ONE 2010, 5, e14445. [CrossRef] [PubMed]

9. Van Huis, A.; Oonincx, D.G.A.B. The environmental sustainability of insects as food and feed. A review. Agron. Sustain. Dev. 2017, 37, 1-14. [CrossRef]

10. Alexander, P.; Brown, C.; Arneth, A.; Dias, C.; Finnigan, J.; Moran, D.; Rounsevell, M.D.A. Could consumption of insects, cultured meat or imitation meat reduce global agricultural land use? Glob. Food Secur. 2017, 15, 22-32. [CrossRef]

11. Oonincx, D.G.A.B.; de Boer, I.J.M. Environmental Impact of the Production of Mealworms as a Protein Source for Humans-A Life Cycle Assessment. PLoS ONE 2012, 7, e51145. [CrossRef] [PubMed]

12. Van Huis, A. Potential of insects as food and feed in assuring food security. Annu. Rev. Entomol. 2013, 58, 563-583. [CrossRef] [PubMed]

13. Looy, H.; Dunkel, F.V.; Wood, J.R. How then shall we eat? Insect-eating attitudes and sustainable foodways. Agric. Hum. Values 2014, 31, 131-141. [CrossRef]

14. Caparros Megido, R.; Sablon, L.; Geuens, M.; Brostaux, Y.; Alabi, T.; Blecker, C.; Drugmand, D.; Haubruge, E.; Francis, F. Edible insects acceptance by Belgian consumers: Promising attitude for entomophagy development. J. Sens. Stud. 2014, 29, 14-20. [CrossRef]

15. Vanhonacker, F.; Van Loo, E.J.; Gellynck, X.; Verbeke, W. Flemish consumer attitudes towards more sustainable food choices. Appetite 2013, 62, 7-16. [CrossRef] [PubMed]

16. Verbeke, W. Profiling consumers who are ready to adopt insects as a meat substitute in a Western society. Food. Qual. Pref. 2015, 39, 147-155. [CrossRef]

17. European Parliament, Council of the European Union. Regulation EC No 258/97 of the European Parliament and of the Council of 27 January 1997 Concerning Novel Foods and Novel Food Ingredients. Off. J. Eur. Union 1997, L43, 1-6.

18. FSA, Food Standards Agency. Emerging Food Technologies: Novel Protein Sources as Food; FSA/11/11/10; FSA: London, UK, 2011.

19. NVWA, Netherlands Food and Consumer Product Safety Authority. Advisory Report on the Risks Associated with the Consumption of Mass-Reared Insects; NVWA/BuRO/2014/2372; NVWA: Utrecht, The Netherlands, 2014.

20. FASFC, Scientific Committee of the Federal Agency for the Safety of the Food Chain. Food Safety Aspects of Insects Intended for Human Consumption; Common Advice SciCom 14-2014 and SHC 9160; FASFC: Oxford, UK, 2014.

21. European Parliament, Council of the European Union. Regulation EU No 2015/2283 of the European Parliament and of the Council of 25 November 2015 on Novel foods, Amending Regulation (EU) No 1169/2011 of the European Parliament and of the Council and repealing Regulation (EC) No 258/97 of the European Parliament and of the Council and Commission Regulation (EC) No 1852/2001. Off. J. Eur. Union 2015, L327, 1-22.

22. Tan, H.S.G.; Fischer, A.R.H.; Tinchan, P.; Stieger, M.; Steenbekkers, L.P.A.; van Trijp, H.C.M. Insects as food: Exploring cultural exposure and individual experience as determinants of acceptance. Food. Qual. Pref. 2015, 42, 78-89. [CrossRef]

23. Laureati, M.; Proserpio, C.; Jucker, C.; Salvoldelli, S. New sustainable protein sources: Consumers' willingness to adopt insects as feed and food. Ital. J. Food Sci. 2016, 28, 652-668.

24. Verneau, F.; La Barbera, F.; Kolle, S.; Amato, M.; Del Giudice, T.; Grunert, K. The effect of communication and implicit associations on consuming insects: An experiment in Denmark and Italy. Appetite 2016, 106, 30-36. [CrossRef] [PubMed]

25. Caparros Megido, R.; Gierts, C.; Blecker, C.; Brostaux, Y.; Haubruge, E.; Alabi, T.; Francis, F. Consumer acceptance of insect-based alternative meat products in Western countries. Food. Qual. Pref. 2016, 52, $237-243$. [CrossRef] 
26. de Boer, J.; Schösler, H.; Boersema, J.J. Motivational differences in food orientation and the choice of snacks made from lentils, locusts, seaweed or "hybrid" meat". Food Qual. Pref. 2013, 28, 32-35. [CrossRef]

27. Hartmann, C.; Shi, J.; Giusto, A.; Siegrist, M. The psychology of eating insects: A cross-cultural comparison between Germany and China. Food Qual. Pref. 2015, 44, 148-156. [CrossRef]

28. Gmuer, A.; Guth, J.N.; Hartmann, C.; Siegrist, M. Effects of the degree of processing of insect ingredients in snacks on expected emotional experiences and willingness to eat. Food Qual. Pref. 2016, 54, 117-127. [CrossRef]

29. Hamerman, E.J. Cooking and disgust sensitivity influence preference for attending insect-based food events. Appetite 2016, 96, 319-326. [CrossRef] [PubMed]

30. Cicatiello, C.; De Rosa, B.; Franco, S.; Lacetera, N. Consumer approach to insects as food: Barriers and potential for consumption in Italy. Br. Food J. 2016, 118, 2271-2286. [CrossRef]

31. Tan, H.S.G.; Fischer, A.R.H.; van Trijp, H.C.M.; Stieger, M. Tasty but nasty? Exploring the role of sensory-liking and food appropriateness in the willingness to eat unusual novel foods like insects. Food Qual. Pref. 2016, 48, 293-302. [CrossRef]

32. Paoletti, M.G.; Buscardo, E.; Vanderjagt, D.J.; Pastuszyn, A.; Pizzoferrato, L.; Huang, Y.S.; Chuang, L.T.; Millson, M.; Cerda, H.; Torres, F.; et al. Nutrient content of earthworms consumed by de Ye' Kuana Amerindians of the Alto Orinoco of Venezuela. Proc. R. Soc. Lond. B 2003, 270, 249-257. [CrossRef] [PubMed]

33. Padulo, C.; Carlucci, L.; Manippa, V.; Marzoli, D.; Saggino, A.; Tommasi, L.; Puglisi-Allegra, S.; Brancucci, A. Valence, familiarity and arousal of different foods in relation to age, sex and weight. Food Qual. Pref. 2017, 57, 104-113. [CrossRef]

34. Tuorila, H.; Keskitalo-Vuokko, K.; Perola, M.; Spector, T.; Kaprio, J. Affective responses to sweet products and sweet solution in British and Finnish adults. Food Qual. Pref. 2017, 62, 128-136. [CrossRef]

35. Donini, L.M.; Serra-Majem, L.; Bulló, M.; Gil, Á.; Salas-Salvadó, J. The Mediterranean diet: Culture, health and science. Br. J. Nutr. 2015, 113, S1-S3. [CrossRef] [PubMed]

36. Lupi, S.; Bagordo, F.; Stefanati, A.; Grassi, T.; Piccinni, L.; Bergamini, M.; De Donno, A. Assessment of lifestyle and eating habits among undergraduate students in northern Italy. Annali dell'Istituto Superiore di Sanita 2015, 51, 154-161. [CrossRef] [PubMed]

37. Schnettler, B.; Miranda, H.; Miranda-Zapata, E.; Salinas-Onate, N.; Grunert, K.G.; Lobos, G.; Sepúlveda, J.; Orellana, L.; Hueche, C.; Bonilla, H. Longitudinal multigroup invariance analysis of the satisfaction with food-related life scale in university students. Appetite 2017, 113, 91-99. [CrossRef] [PubMed]

38. Wardle, J.; Haase, A.M.; Steptoe, A.; Nillapun, M.; Jonwutiwes, K.; Bellisle, F.J. Gender differences in food choice: The contribution of health beliefs and dieting. Ann. Behav. Med. 2004, 27, 107-116. [CrossRef] [PubMed]

39. de Boer, J.; Aiking, H. Prospects for pro-environmental protein consumption in Europe: Cultural, culinary, economic and psychological factors. Appetite 2018, 121, 29-40. [CrossRef] [PubMed]

40. Jun, J.; Arendt, S.W.; Kang, J. Understanding customers' healthful food selection at restaurants: Roles of attitude, gender, and past experience. J. Foodserv. Bus. Res. 2016, 19, 197-212. [CrossRef]

41. Cunha, L.M.; Cabral, D.; Moura, A.P.; Vaz de Almeida, M.D. Application of the Food Choice Questionnaire across cultures: Systematic review of cross-cultural and single country studies. Food Qual. Pref. 2018, 64, 21-36. [CrossRef]

42. Tan, H.S.G.; Verbaan, Y.T.; Stieger, M. How will better products improve the sensory-liking and willingness to buy insect-based foods? Food Res. Int. 2017, 92, 95-105. [CrossRef] [PubMed]

43. FAO. Global Food Losses and Food Waste_Extent, Causes and Prevention; FAO: Rome, Italy, 2011.

(C) 2018 by the authors. Licensee MDPI, Basel, Switzerland. This article is an open access article distributed under the terms and conditions of the Creative Commons Attribution (CC BY) license (http://creativecommons.org/licenses/by/4.0/). 